\title{
Understanding the type 1 reactional state for early diagnosis and treatment: a way to avoid disability in leprosy
}

Compreender melhor o estado reacional tipo 1 para o diagnóstico e tratamento precoces: uma forma de se evitar as incapacidades na hanseníase

\author{
José Augusto da Costa Nery ${ }^{1}$ \\ Fred Bernardes Filho ${ }^{2}$ \\ Juliana Quintanilha ${ }^{3}$
}

\author{
Alice Miranda Machado ${ }^{1}$ \\ Soraya de Souza Chantre Oliveira ${ }^{3}$ \\ Anna Maria Sales ${ }^{4}$
}

\begin{abstract}
A type 1 reaction or reversal reaction is expressed clinically by inflammatory exacerbation of the skin lesions and nerve trunks, consequently leading to sensory and motor alterations. It occurs in non-polar forms of leprosy, although it can occur in a small percentage of sub-polar LL treated patients. Disabilities, deformities and morbidity, still present in leprosy, are mainly caused by these acute episodes. The recognition of reactional states is imperative for an early approach and efficient management, to avoid the emergence of disabilities that stigmatize the disease. This review aims to describe the clinical aspects, immunopathogenesis, epidemiology, histopathological features and therapeutics of type 1 reactions.
\end{abstract}

Keywords: Erythema nodosum; Leprosy; Leprosy, multibacillary; Leprosy, paucibacillary; Mycobacterium leprae

Resumo: A reação do tipo 1 ou reação reversa expressa-se clinicamente por uma exacerbação inflamatória das lesões de pele e de troncos nervosos, levando a alterações sensitivas e motoras. Ocorre nas formas não-polares da hanseníase, embora possa ocorrer numa pequena percentagem de pacientes LL tratados. As incapacidades físicas, deformidades e morbidade, ainda presentes na hanseníase, são causadas principalmente por esses episódios agudos. O reconhecimento dos estados reacionais é imperativo para uma abordagem precoce e manejo adequado, evitando a instalação de incapacidades que tanto estigmatizam a doença. Esta revisão tem como objetivo descrever aspectos clínicos, imunopatogênese, epidemiologia, características histopatológicas e terapêutica do estado reacional do tipo 1.

Palavras-chave: Eritema nodoso; Hanseníase; Hanseníase multibacilar; Hanseníase paucibacilar; Mycobacterium leprae

Received on 23.07.2012.

Approved by the Advisory Board and accepted for publication on 26.11.2012.

* Study carried out at the Leprosy Laboratory of the Oswaldo Cruz Institute - Oswaldo Cruz Foundation (FIOCRUZ) - Rio de Janeiro (RJ), Brazil.

Conflict of interest: None

Financial Support: None

Associate Researcher - Departament of Mycobacteriosis/Leprosy Laboratory of the Oswaldo Cruz Institute - Oswaldo Cruz Foundation (FIOCRUZ) - Rio de Janeiro (RJ), Brazil.

Postgraduate student of Dermatology - Postgraduate Doctor in Dermatology at the Professor Rubem David Azulay da Santa Casa da Misericórdia do Rio de Janeiro Institute of Dermatology (IDPRDA-SCMRJ) - Rio de Janeiro (RJ), Brazil.

Trainee Doctor in the Departament of Mycobacteriosis/Leprosy Laboratory of the Oswaldo Cruz Institute - Oswaldo Cruz Foundation (FIOCRUZ) - Rio de Janeiro (RJ), Brazil.

4 Doctor in Epidemiology - Departament of Mycobacteriosis/Leprosy Laboratory of the Oswaldo Cruz Institute - Oswaldo Cruz Foundation (FIOCRUZ) - Rio de Janeiro (RJ), Brazil. 


\section{INTRODUCTION}

Leprosy reactions are regarded as acute or subacute episodes, characterized by cutaneous and systemic involvement, caused by changes in the status of patients' immune responses. Around $20-50 \%$ of all leprosy patients present reactional states during the course of the disease, which occur most frequently after the start of polychemotherapy. However, reactions can happen before or after treatment. ${ }^{1,2}$ Physical disabilities, deformities and morbidity, still present in leprosy, are caused mainly by these episodes.,4 Leprosy reactions are divided into type 1 reaction (or reversal reaction, RR), and type 2 reaction (or erythema nodosum leprosum, ENL).

Type 1 reactions result from the activation of cell immunity, expressed clinically by exacerbation of skin and nerve trunk inflammation, leading to sensory and motor alterations. Type 2 reactions are acute inflammatory reactions with systemic involvement, entailing the activation of pro-inflammatory cytokines, such as TNF, IL-1, IL-6 and IL-8. In recent years, studies have suggested that cellular immune response is also a factor in triggering ENL episodes. In general, this type of reaction affects other organs, in addition to skin, and coexists with systemic symptoms. There is a third type of reaction called neuritis, affecting the peripheral nerves, characterized by sudden pain or palpation of peripheral nerves, with or without thickening of nerve trunks. ${ }^{5,6}$

Table 1 shows the relationships between the clinical forms of leprosy and the main types of reactional episode that occur.

\section{REVERSAL REACTION}

Type 1 reactions (reversal reactions) occur in the non-polar forms of leprosy and feature mainly in the BT, BB and BL forms, though they can occur in a small number of LL treated patients. ${ }^{1,5,6}$

It is widely accepted that type 1 reactions are associated with the activation of cellular immunity against $M$. leprae antigens, causing inflammation in the skin and nerves. $5,6,7$

\section{IMMUNOPATHOGENESIS}

Many authors have studied the immunological and molecular aspects of reversal reactions but no conclusive mediator or specific molecular diagnostic test has been found that could identify patients with the highest risks of reactional episodes. ${ }^{8,9,10}$

As Roche et al (1991) have noted, it is not clear what factors trigger type 1 reactions, but the combination of positive serology for PGL-1 and positive Mitsuda identifies groups at greater risk of RR. ${ }^{11}$ The increase in immune response to mycobacterian antigens during reversal reactions confirms previous observations from the positive lepromin test, regarding previously negative, sick individuals. ${ }^{12}$ Unfortunately, the activation of macrophages, with the resulting destruction of bacteria, can cause irreversible nerve damage, thus aggravating sensory and motor alterations. ${ }^{13}$

A recent study demonstrated a predominance of the pattern Th-1 (IL-1 $\beta$, TNF, IL-2, IFN-g) in RR lesions, over the pattern Th-2 (IL-4, IL-5 e IL-10), which predominates in multibacillary leprosy. ${ }^{14}$

High levels of TNF- $\alpha$, soluble IL-2 receptor and adhesion molecules also reflect the intensity of local inflammation. ${ }^{15,16}$ Increased expression of TNF- $\alpha$ mRNA in peripheral nerves and skin of patients with the borderline form, was observed in type 1 reactions. ${ }^{17}$

It seems that reversal reactions can be mediated through Th1 lymphocytes, and cells of reactional lesions express the pro-inflammatory cytokines interferon-gamma (IFN- $\gamma$ ), interleukin 12 (IL-12), and oxygen free radicals. ${ }^{18,19}$

Nevertheless, it is not yet known what antigens are involved in RR. It has been demonstrated that macrophages can initiate the neural inflammatory process, even when no $M$. leprae is detected in the neural tissue. Some authors noticed in vitro that $\mathrm{T}$ cells that react to $M$. leprae also react to Schwann cell components. ${ }^{5}$ Barnetson et al. (1976) showed that, although the immunological mechanism is the same, lymphocytes of patients with reversal reactions who only present neuritis, responded to cytoplasmic antigens hidden inside the Schwann cells, whereas in RR cutaneous lesions, superficial antigens were more important..$^{20}$

RR episodes occur mainly during the first six months of polychemotherapy. Isolated neuritis is prevalent in the first 12 months of treatment. However, as noted above, an RR episode can be the

TABLE 1: WHO classification (Ridley \& Jopling, 1966), showing the main type of reactional episode arising in each clinical form. (RR reverse reaction, ENL, erythema nodosum leprosum)

\begin{tabular}{|c|c|c|c|c|}
\hline PAUCIBACILLARY PATIENTS & MULTIBAC & RY PATIENTS & & \\
\hline TT & BT & BB & BL & LL \\
\hline & TYPE I (RR) & TYPE I (RR) & $\begin{array}{l}\text { TYPE II (ENL) } \\
\text { TYPE I (RR) }\end{array}$ & TYPE II (ENL) \\
\hline
\end{tabular}


initial manifestation of leprosy and warrants careful examination, in order to discover signs of neural impairment that could evolve into physical disabilities and deformities.

\section{EPIDEMIOLOGY}

The epidemiology of reversal reactions has been studied, along with the risk factors, in order to promote early medical intervention or prevent their occurrence, given that RRs are considered one of the main causes of most deformities and physical disbailities that are still present in leprosy. ${ }^{21,22}$

The clinical form has been considered a risk factor and $\mathrm{BB}$ and BL patients are at greater risk of RRs than BT patients. ${ }^{23}$ In Brazil, Nery et al. (1998), in a study of multibacillary patients in RRs, found that $59.5 \%$ were BL patients, $33.4 \%$ were $\mathrm{BB}$, and $7.1 \%$ were LL. ${ }^{24}$

RR episodes generally happen in the first six months of polychemotherapy, particularly in "borderline tuberculoid" and "borderline borderline" patients, but longer intervals are seen in "borderline lepromatous" patients. ${ }^{25,26}$ The duration of episodes varies and depends on the clinical form. It can be 3-9 months in BT patients, far longer in BL patients (15 months), and up to two years in LL patients. ${ }^{26}$ The recurrence of reversal reactions becomes a clinical and therapeutic problem, especially when they happen after treatment. RRs tend to recur less than ENL and studies have confirmed that approximately 33\% of patients experience recurrence of reactional leprosy episodes after polychemotherapy. ${ }^{27,28}$

The risk of type 1 reactions is increasing due to several factors, such as vaccination, chemotherapy and puerperium, since there are factors such as: improvement in cell immunity after pregnancy; intercurrent infections; stress; trauma; use of oral contraceptives, among others. . $^{29,30}$

The extent of skin lesions has been identified as an important risk factor for reversal reactions, when examining paucibacillary and multibacillary patients together. VanBrakel and Khawas (1994) have demonstrated that patients with three or more affected body segments are 10 times more likely to experience RRs, as well as the occurrence of neural damage. ${ }^{31}$ Involvement of the face also seems to be a risk factor, as much for RRs as for the development of lagophthalmus. . $^{2,32}$

Nery et al. (1998), in studying multibacillary patients (BB, BL and LL), demonstrated that ENL was predominant among patients with $\mathrm{IB}>3$, while RR was predominant among those with $\mathrm{IB}<3 .{ }^{24}$

\section{Clinical aspects}

RRs are characterized clinically by increased inflammation of pre-existing lesions. Cutaneous lesions that have already shown signs of regression after the start of treatment or lesions in the form of hypochromic macules, become red and edematous, squamous and can even ulcerate, though this is rare. New lesions with the same inflammatory characteristic can appear, as figure 1 illustrates. Edema of the extremities or face can be present, appearing by itself or with other lesions, particularly in BL patients. ${ }^{33}$ Sometimes, edema of the hands and feet are key symptoms of reversal reactions. Nerves can thicken and feel painful, and signs of worsening of a prior peripheral neuropathy (sensory, motor or autonomic) can emerge. Patients can experience a burning sensation in skin lesions, pain in the extremities or on the face, together with a decrease in muscular sensitivity and strength. ${ }^{34}$ The most affected nerves are: the ulnar, median, posterior tibial, common fibular, radial and facial, nerves. Patients can present neural dysfunction, which can manifest as anesthesia, facial paralysis, claw hand or footdrop. ${ }^{26}$ Increased sensitivity in palmar and plantar regions of the feet is also frequent, as well as diffuse nerve damage. ${ }^{35}$ Systemic symptoms, though uncommon, can also emerge, representing a serious clinical condition, with malaise, fever, bone pain, increase of lymph nodes volume, arthralgia and generalized edema. ${ }^{5,6}$

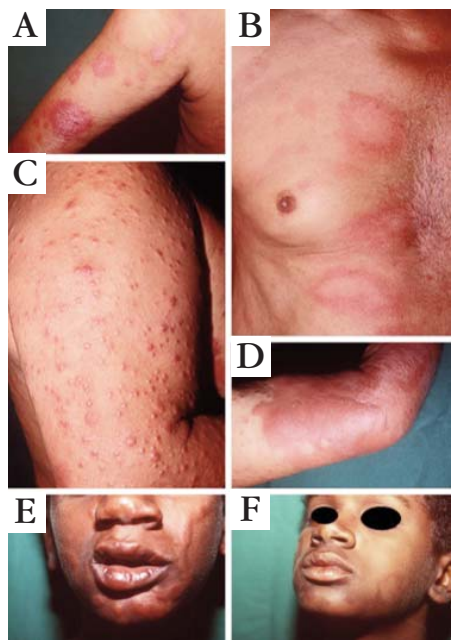

Figure 1: Several clinical aspects of reversal reaction. A: Erythematous, infiltrated, edematous plaques of various sizes, with well-defined edges, situated on the right arm. Some lesions indicate central flaking. B: Erythematous plaques of various sizes, with infiltrated edges, sparing the central region, situated on the anterior trunk. C: Small papules and plaques that appeared suddenly. They are erythematous, infiltrated, with a shiny surface, on the right arm. D: Large erythematous plaque with an edematous appearance, irregular and well-defined edges, revealing small papules and satellite plaques, situated on the anterior surface of the upper member. E: Erythematous plaques with infiltrated, well-defined edges, situated on the face. The patient also presented labial and nasal edema. F: The same patient, showing regression of lesions following the use of prednisone. 
Oliveira et al. (1996) reported macular lesions in multibacillary patients after discharge, called postdischarge macular reversal reaction, which can be addressed quickly using corticosteroids. ${ }^{36}$

Neural impairment is important in the clinical context of RRs and it is considered the leading cause of disabilities and deformities. In accordance with Pearson and Ross (1975), nerve damage results from immune response in hosts to the presence of $M$. leprae antigenic derivatives inside the nerve. ${ }^{37}$ As Job \& Caminho have noted (1989), nerve damage happens during reactional episodes, due to increased intraneural pressure caused by nerve inflammation and intraneural, vascular alterations. ${ }^{38}$ Episodes of neuritis can be very serious, sometimes insidious, or even painless (silent neuritis). ${ }^{26}$ Britton (1998) suggested loss of motor or sensory function in the absence of painful neuritis as a characteristic of reversal reactions.

Silent neuritis, defined as sensory or motor dysfunction without the appearance of cutaneous lesions from reversal reactions or ENL, and without thickening, dormancy, pain or other neurological complaints, is a significant problem for diagnosis and, in these cases, nerve damage is only detected via repeated sensory-motor tests or electromyography. Van Brakel \& Khawas (1994) demonstrated that patients suffering more extensively from the disease, with a greater number of affected nerve trunks, face higher risks of developing silent neuritis. ${ }^{39}$

\section{HISTOPATHOLOGY}

As explained by Ridley (1969), RRs are characterized histopathologically by an influx of mononuclear phagocytes with epithelioid differentiation, rarely forming typical granulomas. The infiltration of lymphocytes was also noted. Edema is a constant characteristic inside and around granulomas, leading to distortion of surrounding tissue and nerves. ${ }^{40}$

The cytology of pre-existing granulomas is modified by a greater differentiation of epithelioid cells, reducing the number of bacilli. There can be Langhans type giant cells, forming granulomas with characteristics of retarded hypersensitivity (Figure 2). When reactions are intense, foci of necrosis can be seen. Inflammatory cells often invade the epidermis and there is an increase in neural destruction. ${ }^{41}$ By analyzing RR lesions before and after treatment with corticosteroids, Alvarenga (1995) demonstrated that epithelioid and giant cells tend to disappear after treatment, involving significant regression of the inflammatory infiltrate during the acute beginning of RR.

\section{TREATMENT}

Treatment for RR aims to suppress the cellular immune response. Early diagnosis and the initiation of the anti-inflammatory therapeutic are essential in order to avoid possible nerve damage. The identification of risk factors is useful since it leads to a more attentive monitoring of patients, allowing for earlier treatment. Importantly, polychemotherapy should be continued throughout the reactional episode, whether it be RR or ENL.

Corticosteroids are the most efficient drugs used for RRs. In 1952, Lowe produced the first report on steroids for leprosy, showing that a 5-day course of cortisone was beneficial in acute manifestations of the disease, including acute neuritis. ${ }^{42}$ Naafs et al. (1979) were the first to associate immunosuppressive effects with improvement in reactional states. ${ }^{43}$ In cases of continual use, the dose and treatment duration for the steroid should be adjusted according to clinical response.

Corticosteroids encourage reduction in vascular permeability and vasodilation through inhibition of mediators, such as metabolites from arachidonic acid (prostaglandins) and inhibition of the liberation of platelet-activating factor (PAF), vasoactive amines, neuropeptides, Il-1, TNF and nitric oxide. ${ }^{44}$ One of the most notable effects of glucocorticoids is the capacity to inhibit the activation of neutrophils and eosinophils, reducing the adherence of these cells through endothelial cells, preventing the migration of polymorphonuclear cells to the area with tissue inflammation. Glucocorticoids also induce: i) inhibition of the phagocytic capacity and production of oxygen free radicals (burst cells); ii) reduction in the number of eosinophils circulating in peripheral blood (causing, at the same time, rough granulation in polymorphonuclear neutrophils); iii) inhibition of tissue
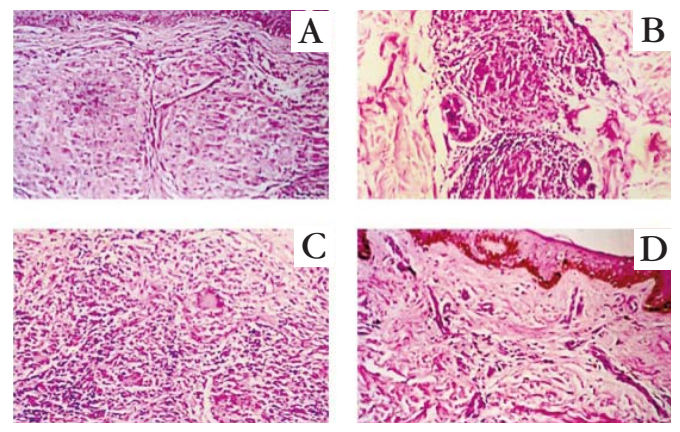

FigURE 2: Histopathological aspects of cutaneous lesions in reversal reactions. A: Skin showing inflammatory infiltrate mostly made up of macrophages with epithelioid cell characteristics, with few lymphocytes. (HE - 250x). B: Involvement of sweat glands due to epithelioid granulomas with few lymphocytes grouped together around the peripheral area (HE - 250x). C: Presence of confluent granulomas with a predominance of epithelioid and giant cells (HE - 250x). D Complete regression of the inflammatory infiltrate after treatment with prednisone. The biopsy was carried out in the same area as the lesion shown in $\mathrm{c}(\mathrm{HE}-250 \mathrm{x})$ 
migration of monocytes and lymphocytes, with an increase in endothelial adhesion of lymphocytes; iv) inhibition of vascular permeability, as well as cellular migration and activation.

Clinically, corticosteroids change the course of RRs in various ways. They reduce intraneural and cutaneous edema, leading to quick improvement of symptoms, and they reduce post-inflammatory scarring. ${ }^{45}$ Their main effect is the suppression of the inflammatory immune response to M.leprae antigens in skin and nerves, probably through interference with the activation of immune cellular response. For these reasons, immunosuppressive doses of corticosteroids should be maintained for a long period of time. ${ }^{46}$

Rose and Waters (1991), and Naafs (1996), recommended an initial dose of $40 \mathrm{mg}$ of prednisone, which was sufficient to control most type 1 reactions. However, patients with neural involvement need higher doses, corresponding to $1 \mathrm{mg} / \mathrm{kg}(60 \mathrm{mg})$ and sometimes even higher $(2 \mathrm{mg} / \mathrm{kg}){ }^{26,45}$

The prednisone dose should only be reduced following evidence of clinical improvement and upon reaching the dose of $20 \mathrm{mg} /$ day. It should be maintained for a long period of time until there is clinical regression and complete recovery of neural functions, when this is the case. ${ }^{47}$ General improvement can happen within three months or take over six months. Pulsotherapy with endovenous methylprednisolone has been employed to facilitate the withdrawl of oral corticosteroids used to control reactional states; the objective is to reduce the side effects and period of morbidity. Indications for pulsotherapy include serious reversal reactions (or reactions that are difficult to control) and acute or chronic cases of neuritis that have already undergone prolonged oral therapy with corticosteroids. The dose is $1 \mathrm{~g}$ of endovenous methylprednisolone, taken as a single daily dose for three days in the first week, followed by $1 \mathrm{~g}$, taken as a single weekly dose for four consecutive weeks, and followed by $1 \mathrm{~g}$, taken as a single monthly dose for four consecutive months. In between pulsotherapy cycles, a dose of $0.5 \mathrm{mg} / \mathrm{kg} /$ day of prednisone is administered. ${ }^{47}$

Immunosuppressants such as azathioprine and cyclosporine A can be used in association (or not) with corticosteroids. ${ }^{48}$

Surgery for decompression of the epineurium is limited and is only recommended in exceptional cases for patients who feel persistent pain after treatment with corticosteroids. Some studies have shown benefits of the surgery in relation to steroids for special cases like nerve abscesses or patients with the TT or BT forms, with neural pain that cannot be treated with immunosuppressants (Britton, 1998). ${ }^{49}$

For the purposes of treating reversal reactions, in accordance with advice from the Brazilian Ministry of Health, prednisone is recommended in the dose of $1-2 \mathrm{mg} / \mathrm{kg} /$ day until there is clinical improvement, followed by fixed intervals. ${ }^{50}$ In cases of clinical worsening, the dose should return to the previous amount. The right dose and reduction of prednisone should be individualized and based on monitoring of sensory functions, via a monofilament test and motor examination (VanBrakel \& Khaw, 1996). As regards the duration of treatment, it is generally: 4-9 months for BT patients; 6-9 months for BB patients; and 6-18 months for BL patients, though it can be up to 24 months or more (Rose \& Waters, 1991). A variety of factors influences response to steroids and the extent of nerve damage, and early initiation of treatment is the most important. Patients with recent neural lesions (less than 6 months in duration) respond better than those who undergo therapy at a later stage (Becx-Bleumink \& Berhe, 1992). 


\section{REFERENCES}

1. Ridley DS, Jopling WH. Classification of leprosy according to immunity: a fivegroup system. Int J Lepr Other Mycobact Dis. 1966;34:255-73.

2. Brito Mde F, Ximenes RA, Gallo ME, Bührer-Sékula S. Association between leprosy reactions after treatment and bacterial load evaluated using anti PGL-I serology and bacilloscopy. Rev Soc Bras Med Trop. 2008;41:67-72.

3. Souza LW. Leprosy reactions in discharged patients following cure by multidrug therapy. Rev Soc Bras Med Trop. 2010;43:737-9.

4. Sousa AR, Costa CO, Queiroz HM, Gonçalves PE, Gonçalves Hde S. Leprosy simulating lichenoid eruption: case report and literature review. An Bras Dermatol. 2010;85:224-6

5. Naafs B. Leprosy reactions. New knowledge. Trop Geogr Med. 1994;46:80-4.

6. Sehgal VN. Reactions in leprosy. Clinical aspects. Int J Dermatol. 1987;26:278-85

7. Sehgal VN, Sharma V. Reactions in leprosy--a prospective study of clinical, bacteriological, immunological and histopathological parameters in thirty-five Indians. J Dermatol. 1988;15:412-9.

8. Lienhardt C, Fine PE. Type 1 reaction, neuritis and disability in leprosy. What is the current epidemiological situation? Lepr Rev. 1994;65:9-33.

9. Giacoia-Gripp CB, Sales AM, Nery JA, Santos-Oliveira JR, de Oliveira AL, Sarno $E N$, et al. Evaluation of cellular phenotypes implicated in immunopathogenesis and monitoring immune reconstitution inflammatory syndrome in HIV/leprosy cases. PLoS One. 2011;6:e28735

10. Lockwood DN, Nicholls P, Smith WC, Das L, Barkataki P, van Brakel W, et al. Comparing the clinical and histological diagnosis of leprosy and leprosy reactions in the INFIR cohort of Indian patients with multibacillary leprosy. PLoS Negl Trop Dis. 2012;6:e1702.

11. Roche PW, Theuvenet WJ, Britton WJ. Risk factors for type-1 reactions in borderline leprosy patients. Lancet. 1991;338:654-7.

12. Jolliffe DS. Leprosy reactional states and their treatment. $\mathrm{Br} J$ Dermatol. 1977:97:345-52.

13. Modlin RL, Melancon-Kaplan J, Young SM, Pirmez C, Kino H, Convit J, et al. Learning from lesions: patterns of tissue inflammation in leprosy. Proc Natl Acad Sci U S A. 1988;85:1213-7.

14. Yamamura M, Wang XH, Ohmen JD, Uyemura K, Rea TH, Bloom BR, et al. Cytokine patterns of immunologically mediated tissue damage. J Immunol. 1992;149:1470-5.

15. Bhattacharya SN, Chattopadhaya D, Saha K. Tumor necrosis factor: status in reactions in leprosy before and after treatment. Int J Dermatol. 1993;32:436-9.

16. Parida SK, Grau GE, Zaheer SA, Mukherjee R. Serum tumor necrosis factor and interleukin 1 in leprosy and during lepra reactions. Clin Immunol Immunopathol. 1992;63:23-7.

17. Khanolkar-Young S, Rayment N, Brickell PM, Katz DR, Vinayakumar S, Colston MJ, et al. Tumour necrosis factor-alpha (TNF-alpha) synthesis is associated with the skin and peripheral nerve pathology of leprosy reversal reactions. Clin Exp Immunol. 1995;99:196-202.

18. Kahawita IP, Walker SL, Lockwood DNJ. Leprosy type 1 reactions and erythema nodosum leprosum. An Bras Dermatol. 2008;83:75-82

19. Little D, Khanolkar-Young S, Coulthart A, Suneetha S, Lockwood DN. Immunohistochemical analysis of cellular infiltrate and gamma interferon, interleukin-12, and inducible nitric oxide synthase expression in leprosy type 1 (reversal) reactions before and during prednisolone treatment. Infect Immun. 2001;69:3413-7.

20. Barnetson RS, Bjune G, Pearson JM, Kronvall G. Cell mediated and humoral immunity in "reversal reactions". Int J Lepr Other Mycobact Dis. 1976;44:267-74.

21. Scollard DM, Smith T, Bhoopat L, Theetranont C, Rangdaeng S, Morens DM. Epidemiologic characteristics of leprosy reactions. Int J Lepr Other Mycobact Dis. 1994;62:559-67.

22. Van Brakel WH, Khawas IB, Lucas SB. Reactions in leprosy: an epidemiological study of 386 patients in west Nepal. Lepr Rev. 1994;65:190-203.

23. Becx-Bleumink M, Berhe D. Occurrence of reactions, their diagnosis and management in leprosy patients treated with multidrug therapy; experience in the leprosy control program of the All Africa Leprosy and Rehabilitation Training Center (ALERT) in Ethiopia. Int J Lepr Other Mycobact Dis. 1992;60:173-84.

24. Nery JA, Vieira LM, de Matos HJ, Gallo ME, Sarno EN. Reactional States in Multibacillary Hansen Disease Patients During Multidrug Therapy. Rev Inst Med Trop Sao Paulo. 1998;40:363-70.

25. Naafs B, Wheate HW. The time interval between the start of anti-leprosy treatment and the development of reactions in borderline patients. Lepr Rev. 1978;49:153-7.
26. Rose P, Waters MF. Reversal reactions in leprosy and their management. Lepr Rev. 1991;62:113-21.

27. Hogeweg M, Kiran KU, Suneetha S. The significance of facial patches and type I reaction for the development of facial nerve damage in leprosy. A retrospective study among 1226 paucibacillary leprosy patients. Lepr Rev. 1991;62:143-9.

28. Lockwood DN, Vinayakumar S, Stanley JN, McAdam KP, Colston MJ. Clinical features and outcome of reversal (type 1) reactions in Hyderabad, India. Int J Lepr Other Mycobact Dis. 1993;61:8-15.

29. Rose $\mathrm{P}, \mathrm{McD}$ ougall $\mathrm{C}$. Adverse reactions following pregnancy in patients with borderline (dimorphous) leprosy. Lepr Rev. 1975;46:109-14.

30. Mastrangelo G, da Silva Neto J, da Silva GV, Scoizzato L, Fadda E, Dallapicola M, et al. Leprosy reactions: the effect of gender and household contacts. Mem Inst Oswaldo Cruz. 2011;106:92-6.

31. Van Brakel WH, Khawas IB. Nerve damage in leprosy: an epidemiological and clinical study of 396 patients in west Nepal--Part 1. Definitions, methods and frequencies. Lepr Rev. 1994;65:204-21.

32. Roche PW, Le Master J, Butlin CR. Risk factors for type 1 reactions in leprosy. Int J Lepr Other Mycobact Dis. 1997;65:450-5.

33. Talhari S, Neves RG, Penna G0, de Oliveira ML, Van-Del-Rey. Hanseníase. Dermatologia Tropical. 4 ed. Manaus: Editora Tropical; 2006.

34. Azulay RD, Azulay DR, Abulafia LA. Micobacterioses. In: Azulay DR. Dermatologia. 5 ed. Rio de Janeiro: Guanabara Koogan; 2011. p. 349-365.

35. Projeto Diretrizes. Hanseníase Neural Primária. Associação Médica Brasileira e Conselho Federal de Medicina; 2011.

36. Oliveira MLW, Gomes MK, Pimentel MIF, Castro MCR. Reação reversa macular pós-alta e poliquimioterapia multibacilar. Hansen Int. 1996;21:46-51.

37. Pearson JM, Ross WF. Nerve involvement in leprosy--pathology, differential diagnosis and principles of management. Lepr Rev. 1975;46:199-212.

38. Job CK. Nerve damage in leprosy. Int J Lepr Other Mycobact Dis. 1989;57:532-9.

39. van Brakel WH, Khawas IB. Silent neuropathy in leprosy: an epidemiological description. Lepr Rev. 1994;65:350-60.

40. Ridley DS. Reactions in leprosy. Lepr Rev. 1969;40:77-81.

41. Sehgal VN, Bhattacharya SN, Sharma VK, Mathur RP. Simultaneous occurrence of upgrading and downgrading type 1 (lepra) reaction. Int J Dermatol. 1990;29:356-7.

42. Lowe J. A.C.T.H. and cortisone in treatment of complications of leprosy. Br Med J. 1952:2:746-9.

43. Naafs B, Pearson JM, Wheate HW. Reversal reaction: the prevention of permanent nerve damage. Comparison of short and long-term steroid treatment. Int J Lepr Other Mycobact Dis. 1979;47:7-12.

44. Beutler B, Krochin N, Milsark IW, Luedke C, Cerami A. Control of cachectin (tumor necrosis factor) synthesis: mechanisms of endotoxin resistance. Science. 1986;232:977-80.

45. Naafs B. Bangkok Workshop on Leprosy Research. Treatment of reactions and nerve damage. Int J Lepr Other Mycobact Dis. 1996;64:S21-8.

46. Moschella SL. An update on the diagnosis and treatment of leprosy. J Am Acad Dermatol. 2004;51:417-26.

47. Nery JAC, Sales AM, Illarramendi X, Duppre NC, Jardim MR, Machado AM. Contribution to diagnosis and management of reactional states: a pratical approach. An Bras Dermatol. 2006;81:367-75

48. Durães SMB, Salles SDAN, Leite VRB, Gazzeta MO. Azathioprine as a steroid sparing agente in leprosy Type 2 reactions: Report of nine cases. Lepr Rev. 2011;82: 304-9.

49. Ebenezer $\mathrm{M}$, Andrews $\mathrm{P}$, Solomon S. Comparative trial of steroids and surgical intervention in the management of ulnar neuritis. Int J Lepr Other Mycobact Dis. 1996;64:282-6.

50. Saúde.gov.br [página da internet]. Ministério da Saúde. Portaria $n^{0} 3.125$, de 07 de outubro de 2010. Aprova as Diretrizes para Vigilância, Atenção e Controle da hanseníase. [acesso 10 Jul 2012]. Disponível em: http://www.saude.es.gov.br/download/portaria_3125_hanseniase_2010.pdf
MAILING ADDRESS:
José Augusto da Costa Nery
Rua Otávio Corrêa, 378 - Urca.
22.291-180 Rio de Janeiro, RJ
Brazil
Email:neryjac@gmail.com

How to cite this article: Nery JAC, Machado AM, Bernardes-Filho F, Oliveira SSC, Quintanilha J, Sales AM. Understanding the type 1 reactional state for early diagnosis and treatment: a way to avoid disability in leprosy. An Bras Dermatol. 2013;88(5):787-92. 